\title{
B cells contribute to MS pathogenesis through antibody-dependent and antibody-independent mechanisms
}

This article was published in the following Dove Press journal:

Biologics:Targets and Therapy

5 May 2012

Number of times this article has been viewed

\author{
Heather L Wilson ${ }^{1,2}$ \\ 'Vaccine and Infectious Disease \\ Organization-International Vaccine \\ Center, ${ }^{2}$ Department of Biochemistry, \\ University of Saskatchewan, \\ Saskatoon, Saskatchewan, Canada
}

\begin{abstract}
For many years, central dogma defined multiple sclerosis (MS) as a T cell-driven autoimmune disorder; however, over the past decade there has been a burgeoning recognition that $\mathrm{B}$ cells contribute to the pathogenesis of certain MS disease subtypes. B cells may contribute to MS pathogenesis through production of autoantibodies (or antibodies directed at foreign bodies, which unfortunately cross-react with self-antigens), through promotion of $\mathrm{T}$ cell activation via antigen presentation, or through production of cytokines. This review highlights evidence for antibody-dependent and antibody-independent B cell involvement in MS pathogenesis.

Keywords: autoantibodies, antibody targets, clinically isolated MS, primary progressive MS, secondary progressive MS, relapsing and remitting MS, T cells, T regulatory cells
\end{abstract}

\section{Introduction}

Multiple sclerosis (MS) is a common and progressive neurological disease that affects over 1 million people worldwide, with the Canadian Prairies showing among the highest incidence rates in the world. ${ }^{1}$ This demyelinating autoimmune disease usually presents in the prime of life and is associated with marked physical and cognitive disabilities and a shortened life span. ${ }^{2}$ Classically described as a neuroinflammatory autoimmune disease that targets the myelin in the brain and spinal cord, this complicated disease has an unknown etiology and no known cure. It presents with varying symptoms such as muscle fatigue, paralysis, loss of sensation/numbness, and pain, as well as emotional impairments such as depression and other mood disorders. The disease has diverse phenotypes. ${ }^{3}$ The majority of MS patients initially present with subacute attacks, with symptoms and signs referable to the central nervous system (CNS) - defined as a clinically isolated syndrome (CIS). ${ }^{4}$ When the attack is followed by a complete or partial remission which is then followed by another attack(s), often focused in a different location in the CNS and possibly of higher intensity, the disease course is defined as relapsing and remitting MS (RRMS). ${ }^{4}$ Patients who present with a gradually progressive course without a well-defined initial attack are presenting with primary progressive MS (PPMS). ${ }^{4}$ Secondary progressive MS (SPMS) is characterized by CIS or RRMS followed by progressive clinical worsening over time, generally 3 years or more after the onset of disease. ${ }^{4}$

The pathology of MS includes penetration of leukocytes across the blood-brain barrier (BBB), intrathecal production of antibodies, and neuroinflammation, which leads to demyelination and astrocytic and/or neuronal/axonal injury. ${ }^{2,5}$ In a recent study, Lucchinetti et al used immunohistochemistry to characterize demyelinating activity, 
inflammatory infiltrates, and the presence of meningeal inflammation in cortical lesions from a cohort of patients with early-stage MS. ${ }^{6}$ They observed that cortical demyelination was common in the early stages of MS, that the majority of cortical lesions studied were positive for $\mathrm{CD}^{+} \mathrm{T}$ cells, and that a subset were positive for $\mathrm{CD} 20^{+} \mathrm{B}$ cells. Further, there was a strong topographic association between cortical demyelination and meningeal inflammation suggesting a direct relationship between inflammation and demyelination. The authors speculate that the reason why inflammatory cortical demyelination is not typically observed in chronic, progressive MS may relate to efficient clearance of cortical inflammation over time and thus does not preclude the possibility that inflammation may contribute to demyelination at its onset. ${ }^{6-11}$ Recent work highlighting how B cells contribute to inflammation and pathogenesis of certain MS disease subtypes are explored in this review. ${ }^{12,13}$

\section{Evidence that intrathecal B cells contribute to MS pathogenesis}

In the majority of MS patients, B cell numbers are elevated in the CNS. ${ }^{14}$ In an extensive histopathological study on actively demyelinating lesions obtained from MS patient biopsies and autopsies, four distinct lesion patterns were observed. ${ }^{15}$ Pattern II lesions, but not lesions following pattern I, II, or IV, were positive for B cells and they had prominent antibody deposition and complement components at sites of active myelin destruction. ${ }^{15}$ In other studies, immunohistochemical analysis of brain and spinal cord sections revealed lymphoid follicle-like structures containing T cells, $B$ cells, and plasma cells in the cerebral meninges in patients with SPMS, but not in patients with RRMS or PPMS. ${ }^{16-18}$ These results suggest de novo formation and maintenance of ectopic lymphoid structures that contribute to increased B cell production in patients with active SPMS. ${ }^{16-18}$ Meningeal B cell follicles were found in close proximity to large subpial gray matter lesions and diffuse meningeal inflammation, which suggests that the lymphoid-like follicles or products produced by them negatively impacted the integrity of the cortical structures and contributed to gray matter cortical demyelination. ${ }^{18,19}$ In a recent study, Lee-Chang et al determined that patients with CIS and RRMS had reduced transitional B cell numbers in the peripheral blood compared to control patients, but of the transitional B cells present, these cells had upregulated surface expression of integrins ( $\alpha 4$ and $\beta 1) .{ }^{20}$ Further, transitional B cells were present in the cerebral spinal fluid (CSF) obtained from the CIS and RRMS patients but they were absent from the CSF of individuals with other inflammatory neurological disease. ${ }^{20}$ Upregulated integrins ( $\alpha 4$ and $\beta 1$ ) likely assist these cells to cross the blood-CSF barrier. Overall, these studies suggest that MS patients have increased intrathecal B cells which may contribute to MS pathogenesis through antibody-dependent or antibody-independent mechanisms.

\section{Antigen-independent mechanisms through which B cells may contribute to MS pathogenesis}

Treatment with rituximab (anti-CD20 antibody, Rituxan ${ }^{\circledR}$ ) a humanized mouse anti-CD20 antibody which depletes CD20+ cells (ie, pre-B cells, immature B cells, mature B cells, and memory B cells, but not stem cells or plasmablasts) - has made it possible to discern whether B cells themselves or their antibody products contribute to MS pathogenesis. In various studies, RRMS patients receiving rituximab showed substantially reduced $\mathrm{B}$ cell numbers in their CSF and serum, reduced levels of emerging inflammatory brain lesions, and reduced frequency of clinical attack despite evidence that antibody levels in the CSF were not immediately decreased, suggesting that B cells contribute to pathology via an antibodyindependent mechanism. ${ }^{21-24}$ Further, a large scale clinical trial wherein patients diagnosed with RRMS were treated with ocrelizumab (a fully humanized anti-CD20 monoclonal antibody with decreased antibody-dependent, cell-mediated cytotoxic effects compared to rituximab) showed that these patients had reduced numbers of yearly relapses, decreased neuroinflammation, and decreased peripheral B cell levels compared with placebo control patients. ${ }^{25}$ Therefore, at least a subset of MS patients treated with anti-CD20 therapy showed improvement of disease, suggesting that B cells can promote pathology through antibody-independent mechanisms. ${ }^{26,27}$

Beyond their role as producers of antibodies, B cells contribute to the induction, maintenance, and reactivation of $\mathrm{CD}^{+}$ $\mathrm{T}$ cells, they act as antigen-presenting cells, they are required for maintenance and reactivation of memory cells, and they modulate $\mathrm{T}$ regulatory $\left(\mathrm{T}_{\mathrm{reg}}\right)$ cell function. ${ }^{28-37}$ Recently, it was reported that the $\mathrm{B}$ cell $\mathrm{CXC}$ chemokine ligand 13 was elevated in serum in RRMS patients with active MS. ${ }^{38}$ In data obtained from clinical trials, the majority of RRMS patients treated with rituximab responded with a proportional decrease in expression of CXC chemokine ligand 13 in the CSF, decreased $\mathrm{B}$ cells in CSF and periphery, and reduced T cells in the CSF. ${ }^{39}$ When B cell effector cytokine responses were compared between MS patients and matched controls, activated B cells derived from MS patients exhibited decreased production of the downregulatory cytokine interleukin-10, a cytokine largely 
produced by naive B cells. ${ }^{40}$ Bar-Or et al showed that activated B cells derived from MS patients exhibited increased expression of the proinflammatory cytokines lymphotoxin $\mathrm{T}$ and tumor necrosis factor $\alpha$, two cytokines largely produced by memory B cells. ${ }^{26}$ When peripheral blood mononuclear cells were subjected to ex vivo B cell depletion, there was reduced $\mathrm{T}$ cell proliferation from the cells obtained from MS patients compared with those from healthy controls. ${ }^{26}$ The authors proposed that the abnormal expression of B cell-derived cytokines mediate "bystander activation" of proinflammatory T cells which may precipitate new relapsing MS disease activity. ${ }^{26}$ If true, these findings offer a potential alternative to antibodydependent mechanism through which rituximab improves MS symptoms in a subset of patients.

$\mathrm{T}_{\text {reg }}$ cells are negative regulators of immune responses to self- and foreign antigens and they play a critical role in maintaining immune tolerance by suppressing pathologic immune responses. ${ }^{41}$ Compared to MS patients with SPMS or healthy controls, patients with RRMS have reduced numbers of $\mathrm{T}_{\text {reg }}$ cells in their peripheral blood but increased numbers of $\mathrm{T}_{\text {reg }}$ cells in the CSF, possibly in an attempt to downregulate local inflammation in the $\mathrm{CNS} .{ }^{42,43} \mathrm{~B}$ cells have also been shown to influence $\mathrm{T}_{\text {reg }}$ cell development, proliferation, and survival in culture. ${ }^{34,35}$ Thus, B cells may promote effector T cell activation while paradoxically they may dampen the adaptive immune response through induction of $\mathrm{T}_{\text {reg }}$ cells. It may be, therefore, that B cells contribute to MS pathogenesis by inappropriately upregulating effector $\mathrm{T}$ cells or inappropriately decreasing $\mathrm{T}_{\text {reg }}$ cells, required to maintain immune tolerance.

\section{Evidence that antibodies contribute to MS pathogenesis}

Immune components and soluble proteins such as serum antibodies pass through the BBB very poorly, if at all. ${ }^{44}$ However, sera from MS patients in exacerbation were shown to have significantly reduced expression of the proteins occludin and vascular endothelial-cadherin compared to MS patients not in exacerbation or compared to normal controls. ${ }^{45}$ These proteins are major components of the tight-junctions which help create the $\mathrm{BBB}$ and their decreased expression in MS patients may result in a more permeable BBB. An in vitro model of BBB serum from SPMS patients showed decreased transendothelial electrical resistance suggesting that serum from SPMS patients affects the permeability of this BBB model. ${ }^{46}$ With increased permeability, the brain may be exposed to a multitude of lymphocytes, blood proteins, and antibodies from which they are usually isolated. ${ }^{47}$ Because the BBB may be transiently semipermeable in at least some
MS clinical disease subtypes, it is conceivable that circulating antibodies may enter the CNS and, if they share affinity for antigens found in the brain, contribute to pathology. ${ }^{2,5,48}$ Indeed, serum levels in a patient with RRMS showed higher serum myelin oligodendrocyte glycoprotein (MOG) and myelin basic protein (MBP) antibodies in times of relapse relative to times of remission further indicating that the $\mathrm{BBB}$ in patients with MS may be transiently semipermeable. ${ }^{47}$

The majority of patients with MS present with elevated intrathecal antibody titers. ${ }^{14,49-51}$ When CSF obtained from patients with MS has been subjected to isoelectric focusing, a technique used to separate proteins by their electrical charge, a pattern of oligoclonal bands becomes evident. ${ }^{48,52-54}$ Because they have limited heterogeneity, intrathecal B cells undergoing clonal expansion and somatic hypermutation of the expressed antibody gene rearrangement are visualized as oligoclonal bands. ${ }^{12,55,56}$ In contrast, serum-derived antibodies are produced by a myriad of heterogeneous B cells and thus show a pattern of polyclonal banding upon isoelectric focusing. ${ }^{55-57}$ The majority of oligoclonal bands are complement-activating immunoglobulin (Ig) G1 isotype. ${ }^{58}$ Histopathology performed on pattern II demyelinating lesions obtained from MS patient biopsies and autopsies showed prominent antibody deposition and complement components at sites of active myelin destruction. ${ }^{15}$ Other studies showed that patients with pattern II histopathologic lesions responded well to plasma exchange. ${ }^{59}$ Through magnetic resonance imaging and examination of CSF from patients in the early phases of MS, it was determined that an association between intrathecal antibody synthesis and cortical lesions was highly predictive of an earlier CIS conversion to MS and of higher disease activity. ${ }^{60}$ Further, in contrast with patients diagnosed with RRMS or PPMS, patients diagnosed with SPMS who responded positively to treatment with rituximab showed a decline in intrathecal antibody production as well as decreased B cell numbers. ${ }^{61}$ Thus, in at least subsets of MS patients, antibodies likely contribute to MS pathogenesis. ${ }^{59,62-64}$

There is precedence that autoantibodies contribute to neurological pathology and disease. Although recently defined as pathologically distinct from MS, many clinicians still consider neuromyelitis optica (NMO; optic-spinal MS) as a part of the MS disease spectrum. ${ }^{65} \mathrm{NMO}$-associated IgG antibodies are present in the serum of $70 \%$ of patients with NMO. ${ }^{66}$ Patients with NMO respond positively to plasma exchange, which suggests that autoantibodies contribute to the pathogenesis of this autoimmune disease. ${ }^{67}$ Through a series of elegant experiments, researchers at the Mayo 
Clinic showed that NMO-associated antibodies precipitated Aquaporin 4 from astrocyte cell membranes and definitively established that Aquaporin 4 is the target. ${ }^{67}$ Hence, because a pathogenic autoantibody contributes to the neuroinflammatory disorder $\mathrm{NMO}$, it is reasonable to speculate that distinct pathogenic autoantibodies may contribute to other neuroinflammatory disorders such as MS.

\section{Identification antibodies targets which contribute to MS pathogenesis \\ Foreign antigens}

Previous infection with Epstein-Barr virus (EBV) - a virus with lifelong persistence in the host's B cells - is an established MS risk factor. ${ }^{68,69}$ Whether antibodies against viral proteins contribute to MS pathogenesis by binding to the viral antigen or by binding self-antigens - which share significant morphology to the viral antigen - is currently under investigation. Jaquiery et al assessed EBV-specific humoral and cellular immune responses in the CSF of patients with early MS compared to persons with other inflammatory neurological diseases, noninflammatory neurological diseases, or neurotropic herpesvirus cytomegalovirus (used as a control). ${ }^{70}$ They observed enriched intrathecal $\mathrm{CD} 8^{+}$ cytotoxic $\mathrm{T}$ cells and increased antibody indexes for viral capsid antigen and EBV nuclear antigen 1 (EBNA-1), but not cytomegalovirus antibody indexes, in early MS as compared with other inflammatory neurological diseases and noninflammatory neurological diseases patients. ${ }^{70}$ Further, in a survey of 100 subjects with CIS, RRMS, or PPMS over a 5-year period, all of whom had serologic evidence of previous EBV infection, patients with RRMS had significantly higher anti-EBNA-1 titers (a marker of the latent phase of the virus) and gadolinium-enhanced lesions on magnetic resonance images compared with patients with PPMS or CIS. ${ }^{71}$ In contrast, Jafari et al - who evaluated anti-EBV antibody response in serum and CSF from a large cohort of patients determined that there was no evidence for elevated intrathecal anti-EBNA-1 IgG synthesis in MS patients relative to control patients when total IgG content of paired serum and CSF samples were normalized. ${ }^{72}$ Further, it was determined that although MS risk tended to be higher in individuals with high titers of neutralizing antibodies against EBV compared to those with low titers, this association was attenuated after adjustment for anti-EBNA-1 IgG antibody titres. ${ }^{73}$ Therefore, although there appears to be a strong association between prior EBV exposure and risk of MS, whether antibodies against viral proteins contribute to MS pathogenesis has not yet been definitively established.

\section{Self-antigens}

It has proven challenging to definitively identify the antibody targets to which pathogenic autoantibodies bind. While there is evidence that autoantibodies derived from MS patients bind lipids, ${ }^{54}$ carbohydrates,${ }^{74,75}$ and DNA, ${ }^{76}$ the vast majority of research has focused on investigating proteins which comprise the myelin sheath such as MBP, MOG, and proteolipid protein as autoantibody targets. Elevated antibody titers against MBP and/or MOG have been reported in serum and CSF derived from MS patients ${ }^{77,78}$ and serum antibodies to MBP and MOG were observed in subgroups of patients with MS, ${ }^{79,80}$ which suggests that autoantibodies specific for myelin-derived proteins may contribute to MS pathogenesis. However, myelin-specific antibodies can also be detected in healthy controls suggesting that these targets are not definitively predictive of disease. ${ }^{81,82}$ Further, although recombinant monoclonal antibodies generated from B cells obtained from CSF from MS patients showed reactivity to sites of degrading myelin and axons, specific reactivity to MOG, MBP, or proteolipid protein could not be confirmed. ${ }^{83-85}$ Thus, pathogenic antibodies which specifically contribute to MS disease remain elusive, ${ }^{49}$ and it may be beneficial to expand autoantibody screening beyond myelin-based proteins. CSF and sera from control and MS patients have been screened for autoantibodies using several approaches including phage display libraries, which are constructed using short peptides to mimic epitopes, ${ }^{86-89}$ a human brain complementary DNA expression library, ${ }^{90}$ human antigen microarrays, ${ }^{91,92}$ and a cell-based proteomic approach. ${ }^{93}$ Such techniques use short, linear amino acid segments to represent antibody binding sites, but these artificial targets fail to identify autoantibodies whose epitopes are comprised of nonadjacent amino acids brought into close proximity through conformational folding of the antigen. Alternatively, they use recombinant antigens which lack posttranslational modification which may be critical for antibody-antigen binding. Studies focused on identifying pathogenic autoantibody targets, which take into account epitopes comprised of nonadjacent amino acids and/or posttranslational modifications, are needed to identify MS biomarkers and therapeutic approaches to prevent or combat MS.

\section{Conclusion}

Although the vast majority of MS patients have elevated intrathecal antibody levels, identification of the definitive 
antibody targets has remained elusive. Beyond their role in antibody production, intrathecal B cells may contribute to activation/reactivation of effector $\mathrm{T}$ cells and the modulation of $\mathrm{T}_{\text {reg }}$ cells, which may contribute to MS pathogenesis. Targeted depletion of pathogenic intrathecal plasma cells/B cells which both eliminate pathogenic antibody production and thwart inappropriate $\mathrm{T}$ cell responsiveness may serve as an effective preventative or treatment method in patients with MS.

\section{Acknowledgments}

I gratefully acknowledge my collaboration with Dr Christopher Power, University of Alberta, which has exposed me to this area of study. I also am grateful for Dr Christine A Webber for her critical reading of this manuscript. HLW is supported by a research grant provided by Saskatchewan Agriculture Development Fund. This manuscript is published with the permission of the Director of Vaccine and Infectious Disease Organization-International Vaccine Center as journal series no 633 .

\section{Disclosure}

The author reports no conflicts of interest in this work.

\section{References}

1. Beck CA, Metz LM, Svenson LW, Patten SB. Regional variation of multiple sclerosis prevalence in Canada. Mult Scler. 2005;11(5): 516-519.

2. Paty DW, Ebers GC. Clinical features. In: Paty DE, Ebers GC, editors. Multiple Sclerosis, Volume 50. Philadelphia, PA: FA Davis Company; 1997:135-191.

3. Hurwitz BJ. The diagnosis of multiple sclerosis and the clinical subtypes. Ann Indian Acad Neurol. 2009;12(4):226-230.

4. Ebers GC. Natural history of multiple sclerosis. J Neurol Neurosurg Psychiatry. 2001;71 Supp1 2:ii16-ii19.

5. Opdenakker G, Van Damme J. Probing cytokines, chemokines and matrix metalloproteinases towards better immunotherapies of multiple sclerosis. Cytokine Growth Factor Rev. 2011;22(5-6):359-365.

6. Lucchinetti CF, Popescu BF, Bunyan RF, et al. Inflammatory cortical demyelination in early multiple sclerosis. N Engl J Med. 2011;365(23): 2188-2197.

7. Peterson JW, Bo L, Mork S, Chang A, Trapp BD. Transected neurites, apoptotic neurons, and reduced inflammation in cortical multiple sclerosis lesions. Ann Neurol. 2001;50(3):389-400.

8. Wegner C, Esiri MM, Chance SA, Palace J, Matthews PM. Neocortical neuronal, synaptic, and glial loss in multiple sclerosis. Neurology. 2006;67(6):960-967.

9. Vercellino M, Plano F, Votta B, Mutani R, Giordana MT, Cavalla P. Grey matter pathology in multiple sclerosis. J Neuropathol Exp Neurol. 2005;64(12):1101-1107.

10. Merkler D, Ernsting T, Kerschensteiner M, Bruck W, Stadelmann C. A new focal EAE model of cortical demyelination: multiple sclerosislike lesions with rapid resolution of inflammation and extensive remyelination. Brain. 2006;129(Pt 8):1972-1983.

11. Lassmann H, Kitz K, Wisniewski HM. Histogenesis of demyelinating lesions in the spinal cord of guinea pigs with chronic relapsing experimental allergic encephalomyelitis. J Neurol Sci. 1981;50(1):109-121.
12. Baranzini SE, Jeong MC, Butunoi C, Murray RS, Bernard CC, Oksenberg JR. B cell repertoire diversity and clonal expansion in multiple sclerosis brain lesions. J Immunol. 1999;163(9):5133-5144.

13. Qin Y, Duquette P, Zhang Y, et al. Intrathecal B-cell clonal expansion, an early sign of humoral immunity, in the cerebrospinal fluid of patients with clinically isolated syndrome suggestive of multiple sclerosis. Lab Invest. 2003;83(7):1081-1088.

14. Cepok S, Rosche B, Grummel V, et al. Short-lived plasma blasts are the main B cell effector subset during the course of multiple sclerosis Brain. 2005;128(Pt 7):1667-1676.

15. Lucchinetti C, Bruck W, Parisi J, Scheithauer B, Rodriguez M, Lassmann $\mathrm{H}$. Heterogeneity of multiple sclerosis lesions: implications for the pathogenesis of demyelination. Ann Neurol. 2000;47(6):707-717.

16. Martin F, Chan AC. B cell immunobiology in disease: evolving concepts from the clinic. Annu Rev Immunol. 2006;24:467-496.

17. Serafini B, Rosicarelli B, Magliozzi R, Stigliano E, Aloisi F. Detection of ectopic B-cell follicles with germinal centers in the meninges of patients with secondary progressive multiple sclerosis. Brain Pathol. 2004;14(2):164-174.

18. Magliozzi R, Howell O, Vora A, et al. Meningeal B-cell follicles in secondary progressive multiple sclerosis associate with early onset of disease and severe cortical pathology. Brain. 2007;130(Pt 4):1089-1104.

19. Howell OW, Reeves CA, Nicholas R, et al. Meningeal inflammation is widespread and linked to cortical pathology in multiple sclerosis. Brain. 2011;134(Pt 9):2755-2771.

20. Lee-Chang C, Top I, Zephir H, et al. Primed status of transitional B cells associated with their presence in the cerebrospinal fluid in early phases of multiple sclerosis. Clin Immunol. 2011;139(1):12-20.

21. Petereit HF, Moeller-Hartmann W, Reske D, Rubbert A. Rituximab in a patient with multiple sclerosis - effect on B cells, plasma cells and intrathecal IgG synthesis. Acta Neurol Scand. 2008;117(6): 399-403.

22. Hauser SL, Waubant E, Arnold DL, et al. B-cell depletion with rituximab in relapsing-remitting multiple sclerosis. $N$ Engl $\mathrm{J}$ Med. 2008;358(7):676-688.

23. Martin Mdel P, Cravens PD, Winger R, et al. Depletion of B lymphocytes from cerebral perivascular spaces by rituximab. Arch Neurol. 2009;66(8):1016-1020.

24. Stuve O, Cepok S, Elias B, et al. Clinical stabilization and effective B-lymphocyte depletion in the cerebrospinal fluid and peripheral blood of a patient with fulminant relapsing-remitting multiple sclerosis. Arch Neurol. 2005;62(10):1620-1623.

25. Kappos L, Li D, Calabresi PA, et al. Ocrelizumab in relapsing-remitting multiple sclerosis: a phase 2, randomised, placebo-controlled, multicentre trial. Lancet. 2011;378(9805):1779-1787.

26. Bar-Or A, Fawaz L, Fan B, et al. Abnormal B-cell cytokine responses a trigger of T-cell-mediated disease in MS? Ann Neurol. 2010;67(4):452-461.

27. Weber MS, Prod'homme T, Patarroyo JC, et al. B-cell activation influences T-cell polarization and outcome of anti-CD20 B-cell depletion in central nervous system autoimmunity. Ann Neurol. 2010;68(3): 369-383.

28. Lund FE, Randall TD. Effector and regulatory B cells: modulators of CD4(+) T cell immunity. Nat Rev Immunol. 2010;10(4):236-247.

29. Lund FE, Hollifield M, Schuer K, Lines JL, Randall TD, Garvy BA. $\mathrm{B}$ cells are required for generation of protective effector and memory CD4 cells in response to Pneumocystis lung infection. J Immunol. 2006;176(10):6147-6154.

30. Lund FE, Garvy BA, Randall TD, Harris DP. Regulatory roles for cytokine-producing B cells in infection and autoimmune disease. Curr Dir Autoimmun. 2005;8:25-54.

31. Liu Q, Liu Z, Rozo CT, et al. The role of B cells in the development of $\mathrm{CD} 4$ effector $\mathrm{T}$ cells during a polarized $\mathrm{Th} 2$ immune response. J Immunol. 2007;179(6):3821-3830.

32. Wojciechowski W, Harris DP, Sprague F, et al. Cytokine-producing effector B cells regulate type 2 immunity to $\mathrm{H}$. polygyrus. Immunity. 2009;30(3):421-433. 
33. Whitmire JK, Asano MS, Kaech SM, et al. Requirement of B cells for generating CD4+ T cell memory. J Immunol. 2009;182(4): $1868-1876$

34. Chen LC, Delgado JC, Jensen PE, Chen X. Direct expansion of human allospecific FoxP3+CD4+ regulatory $\mathrm{T}$ cells with allogeneic $\mathrm{B}$ cells for therapeutic application. J Immunol. 2009;183(6):4094-4102.

35. Tu W, Lau YL, Zheng J, et al. Efficient generation of human alloantigenspecific CD4+ regulatory $\mathrm{T}$ cells from naive precursors by CD40activated B cells. Blood. 2008;112(6):2554-2562.

36. Toubi E, Kessel A, Slobodin G, et al. Changes in macrophage function after rituximab treatment in patients with rheumatoid arthritis. Ann Rheum Dis. 2007;66(6):818-820.

37. Kessel A, Rosner I, Toubi E. Rituximab: beyond simple B cell depletion. Clin Rev Allergy Immunol. 2008;34(1):74-79.

38. Festa ED, Hankiewicz K, Kim S, et al. Serum levels of CXCL13 are elevated in active multiple sclerosis. Mult Scler. 2009;15(11): 1271-1279.

39. Piccio L, Naismith RT, Trinkaus $\mathrm{K}$, et al. Changes in B- and T-lymphocyte and chemokine levels with rituximab treatment in multiple sclerosis. Arch Neurol. 2010;67(6):707-714.

40. Duddy M, Niino M, Adatia F, et al. Distinct effector cytokine profiles of memory and naive human B cell subsets and implication in multiple sclerosis. J Immunol. 2007;178(10):6092-6099.

41. Joffre O, van Meerwijk JP. CD4+CD25+ regulatory T lymphocytes in bone marrow transplantation. Semin Immunol. 2006;18(2):128-135.

42. Venken K, Hellings N, Thewissen M, et al. Compromised CD4+ $\mathrm{CD} 25$ (high) regulatory T-cell function in patients with relapsingremitting multiple sclerosis is correlated with a reduced frequency of FOXP3-positive cells and reduced FOXP3 expression at the single-cell level. Immunology. 2008;123(1):79-89.

43. Fritzsching B, Haas J, Konig F, et al. Intracerebral human regulatory T cells: analysis of CD4+ CD25+ FOXP3+ T cells in brain lesions and cerebrospinal fluid of multiple sclerosis patients. PLoS One. 2011;6(3):e17988.

44. Banks WA. Are the extracellular pathways a conduit for the delivery of therapeutics to the brain? Curr Pharm Des. 2004;10(12):1365-1370.

45. Minagar A, Ostanin D, Long AC, et al. Serum from patients with multiple sclerosis downregulates occludin and VE-cadherin expression in cultured endothelial cells. Mult Scler. 2003;9(3):235-238.

46. Proia P, Schiera G, Salemi G, Ragonese P, Savettieri G, Di Liegro I. Neuronal and BBB damage induced by sera from patients with secondary progressive multiple sclerosis. Int J Mol Med. 2009;24(6): 743-747.

47. Angelucci F, Mirabella M, Frisullo G, Caggiula M, Tonali PA, Batocchi AP. Serum levels of anti-myelin antibodies in relapsing-remitting multiple sclerosis patients during different phases of disease activity and immunomodulatory therapy. Dis Markers. 2005;21(2):49-55.

48. Cross AH, Wu GF. Multiple sclerosis: oligoclonal bands still yield clues about multiple sclerosis. Nat Rev Neurol. 2010;6(11): 588-589.

49. Awad A, Hemmer B, Hartung HP, Kieseier B, Bennett JL, Stuve O. Analyses of cerebrospinal fluid in the diagnosis and monitoring of multiple sclerosis. J Neuroimmunol. 2010;219(1-2):1-7.

50. Meinl E, Krumbholz M, Hohlfeld R. B lineage cells in the inflammatory central nervous system environment: migration, maintenance, local antibody production, and therapeutic modulation. Ann Neurol. 2006;59(6):880-892.

51. Obermeier B, Mentele R, Malotka J, et al. Matching of oligoclonal immunoglobulin transcriptomes and proteomes of cerebrospinal fluid in multiple sclerosis. Nat Med. 2008;14(6):688-693.

52. Tintore M, Rovira A, Rio J, et al. Do oligoclonal bands add information to MRI in first attacks of multiple sclerosis? Neurology. 2008;70(13 Pt 2):1079-1083.

53. Villar LM, Sadaba MC, Roldan E, et al. Intrathecal synthesis of oligoclonal IgM against myelin lipids predicts an aggressive disease course in MS. J Clin Invest. 2005;115(1):187-194.
54. Brennan KM, Galban-Horcajo F, Rinaldi S, et al. Lipid arrays identify myelin-derived lipids and lipid complexes as prominent targets for oligoclonal band antibodies in multiple sclerosis. J Neuroimmunol. 2011;238(1-2):87-95.

55. Qin Y, Duquette P, Zhang Y, Talbot P, Poole R, Antel J. Clonal expansion and somatic hypermutation of $\mathrm{V}(\mathrm{H})$ genes of $\mathrm{B}$ cells from cerebrospinal fluid in multiple sclerosis. $J$ Clin Invest. 1998;102(5):1045-1050.

56. Owens GP, Kraus H, Burgoon MP, Smith-Jensen T, Devlin ME, Gilden DH. Restricted use of VH4 germline segments in an acute multiple sclerosis brain. Ann Neurol. 1998;43(2):236-243.

57. Ritchie AM, Gilden DH, Williamson RA, et al. Comparative analysis of the CD19+ and CD138+ cell antibody repertoires in the cerebrospinal fluid of patients with multiple sclerosis. J Immunol. 2004;173(1): 649-656.

58. Storch MK, Piddlesden S, Haltia M, Iivanainen M, Morgan P, Lassmann H. Multiple sclerosis: in situ evidence for antibody- and complement-mediated demyelination. Ann Neurol. 1998;43(4):465-471.

59. Keegan M, Konig F, McClelland R, et al. Relation between humoral pathological changes in multiple sclerosis and response to therapeutic plasma exchange. Lancet. 2005;366(9485):579-582.

60. Calabrese M, Federle L, Bernardi V, et al. The association of intrathecal immunoglobulin synthesis and cortical lesions predicts disease activity in clinically isolated syndrome and early relapsing-remitting multiple sclerosis. Mult Scler. 2012;18(2):174-180.

61. Rommer PS, Patejdl R, Winkelmann A, Benecke R, Zettl UK. Rituximab for secondary progressive multiple sclerosis: a case series. CNS Drugs. 2011;25(7):607-613

62. Weiner HL, Dau PC, Khatri BO, et al. Double-blind study of true vs sham plasma exchange in patients treated with immunosuppression for acute attacks of multiple sclerosis. Neurology. 1989;39(9):1143-1149.

63. Zettl UK, Hartung HP, Pahnke A, Brueck W, Benecke R, Pahnke J. Lesion pathology predicts response to plasma exchange in secondary progressive MS. Neurology. 2006;67(8):1515-1516.

64. Weinshenker BG, O’Brien PC, Petterson TM, et al. A randomized trial of plasma exchange in acute central nervous system inflammatory demyelinating disease. Ann Neurol. 1999;46(6):878-886.

65. Rejdak K, Jackson S, Giovannoni G. Multiple sclerosis: a practical overview for clinicians. Br Med Bull. 2010;95(1):79-104.

66. Lennon VA, Wingerchuk DM, Kryzer TJ, et al. A serum autoantibody marker of neuromyelitis optica: distinction from multiple sclerosis. Lancet. 2004;364(9451):2106-2112.

67. Lennon VA, Kryzer TJ, Pittock SJ, Verkman AS, Hinson SR. IgG marker of optic-spinal multiple sclerosis binds to the aquaporin-4 water channel. J Exp Med. 2005;202(4):473-477.

68. Warner HB, Carp RI. Multiple sclerosis and Epstein-Barr virus. Lancet. 1981;2(8258):1290.

69. Ascherio A, Munger KL. Epstein-Barr virus infection and multiple sclerosis: a review. J Neuroimmune Pharmacol. 2010;5(3):271-277.

70. Jaquiery E, Jilek S, Schluep M, et al. Intrathecal immune responses to EBV in early MS. Eur J Immunol. 2010;40(3):878-887.

71. Farrell RA, Antony D, Wall GR, et al. Humoral immune response to EBV in multiple sclerosis is associated with disease activity on MRI. Neurology. 2009;73(1):32-38.

72. Jafari N, van Nierop GP, Verjans GM, Osterhaus AD, Middeldorp JM, Hintzen RQ. No evidence for intrathecal IgG synthesis to Epstein Barr virus nuclear antigen-1 in multiple sclerosis. J Clin Virol. 2010;49(1):26-31.

73. Simon KC, O'Reilly EJ, Munger KL, Finerty S, Morgan AJ, Ascherio A. Epstein-Barr virus neutralizing antibody levels and risk of multiple sclerosis. Mult Scler. 2012; January 30. [Epub ahead of print.]

74. Schwarz M, Spector L, Gortler M, et al. Serum anti-Glc(alpha1,4) Glc(alpha) antibodies as a biomarker for relapsing-remitting multiple sclerosis. J Neurol Sci. 2006;244(1-2):59-68.

75. Lolli F, Mulinacci B, Carotenuto A, et al. An N-glucosylated peptide detecting disease-specific autoantibodies, biomarkers of multiple sclerosis. Proc Natl Acad Sci U S A. 2005;102(29):10273-10278. 
76. Williamson RA, Burgoon MP, Owens GP, et al. Anti-DNA antibodies are a major component of the intrathecal $\mathrm{B}$ cell response in multiple sclerosis. Proc Natl Acad Sci U S A. 2001;98(4):1793-1798.

77. Reindl M, Linington $\mathrm{C}$, Brehm U, et al. Antibodies against the myelin oligodendrocyte glycoprotein and the myelin basic protein in multiple sclerosis and other neurological diseases: a comparative study. Brain. 1999; 122(Pt 11):2047-2056.

78. Schmidt S, Haase CG, Bezman L, et al. Serum autoantibody responses to myelin oligodendrocyte glycoprotein and myelin basic protein in $\mathrm{X}$-linked adrenoleukodystrophy and multiple sclerosis. J Neuroimmunol. 2001;119(1):88-94.

79. Zhou D, Srivastava R, Nessler S, et al. Identification of a pathogenic antibody response to native myelin oligodendrocyte glycoprotein in multiple sclerosis. Proc Natl Acad Sci U S A. 2006;103(50): 19057-19062.

80. Lalive PH, Menge T, Delarasse C, et al. Antibodies to native myelin oligodendrocyte glycoprotein are serologic markers of early inflammation in multiple sclerosis. Proc Natl Acad Sci U S A. 2006;103(7):2280-2285.

81. Karni A, Bakimer-Kleiner R, Abramsky O, Ben-Nun A. Elevated levels of antibody to myelin oligodendrocyte glycoprotein is not specific for patients with multiple sclerosis. Arch Neurol. 1999;56(3): 311-315.

82. Lampasona V, Franciotta D, Furlan R, et al. Similar low frequency of anti-MOG IgG and IgM in MS patients and healthy subjects. Neurology. 2004;62(11):2092-2094.

83. von Budingen HC, Harrer MD, Kuenzle S, Meier M, Goebels N. Clonally expanded plasma cells in the cerebrospinal fluid of MS patients produce myelin-specific antibodies. Eur J Immunol. 2008;38(7):2014-2023.

84. Owens GP, Bennett JL, Lassmann H, et al. Antibodies produced by clonally expanded plasma cells in multiple sclerosis cerebrospinal fluid. Ann Neurol. 2009;65(6):639-649.
85. Zhang Y, Da RR, Guo W, et al. Axon reactive B cells clonally expanded in the cerebrospinal fluid of patients with multiple sclerosis. J Clin Immunol. 2005;25(3):254-264.

86. Scott JK, Smith GP. Searching for peptide ligands with an epitope library. Science. 1990;249(4967):386-390.

87. Cortese I, Tafi R, Grimaldi LM, Martino G, Nicosia A, Cortese R. Identification of peptides specific for cerebrospinal fluid antibodies in multiple sclerosis by using phage libraries. Proc Natl Acad Sci USA. 1996;93(20):11063-11067.

88. Somers V, Govarts C, Somers K, Hupperts R, Medaer R, Stinissen P. Autoantibody profiling in multiple sclerosis reveals novel antigenic candidates. J Immunol. 2008;180(6):3957-3963.

89. Rand KH, Houck H, Denslow ND, Heilman KM. Molecular approach to find target(s) for oligoclonal bands in multiple sclerosis. $J$ Neurol Neurosurg Psychiatry. 1998;65(1):48-55.

90. Cepok S, Zhou D, Srivastava R, et al. Identification of Epstein-Barr virus proteins as putative targets of the immune response in multiple sclerosis. J Clin Invest. 2005;115(5):1352-1360.

91. Quintana FJ, Farez MF, Viglietta V, et al. Antigen microarrays identify unique serum autoantibody signatures in clinical and pathologic subtypes of multiple sclerosis. Proc Natl Acad Sci USA. 2008;105(48): 18889-18894.

92. Quintana FJ, Farez MF, Izquierdo G, Lucas M, Cohen IR, Weiner HL. Antigen microarrays identify CNS-produced autoantibodies in RRMS Neurology. 2012;78(8):532-539.

93. Mathey EK, Derfuss T, Storch MK, et al. Neurofascin as a novel target for autoantibody-mediated axonal injury. $J$ Exp Med. 2007;204(10) 2363-2372.
Biologics: Targets \& Therapy

\section{Publish your work in this journal}

Biologics: Targets \& Therapy is an international, peer-reviewed journal focusing on the patho-physiological rationale for and clinical application of Biologic agents in the management of autoimmune diseases, cancers or other pathologies where a molecular target can be identified. This journal is indexed on PubMed Central, CAS, EMBase, Scopus

\section{Dovepress}

and the Elsevier Bibliographic databases. The manuscript management system is completely online and includes a very quick and fair peerreview system, which is all easy to use. Visit http://www.dovepress. com/testimonials.php to read real quotes from published authors. 